\begin{tabular}{|l|l|l||}
\hline \multicolumn{2}{|c|}{ PublisherInfo } \\
\hline \hline PublisherName & $:$ & BioMed Central \\
\hline \hline PublisherLocation & $:$ & London \\
\hline \hline PublisherImprintName & $:$ & BioMed Central \\
\hline \hline
\end{tabular}

\title{
AKT signalling implicated in failure of endocrine therapy
}

\begin{tabular}{||l|l|l||}
\hline \multicolumn{2}{|c|}{ ArticleInfo } \\
\hline \hline ArticleID & $:$ & 3795 \\
\hline \hline ArticleDOI & $:$ & $10.1186 /$ bcr-2002-76350 \\
\hline \hline ArticleCitationID & $:$ & 76350 \\
\hline \hline ArticleSequenceNumber & $:$ & 18 \\
\hline \hline ArticleCategory & $:$ & Paper Report \\
\hline \hline ArticleFirstPage & $:$ & 1 \\
\hline \hline ArticleLastPage & $:$ & 4 \\
\hline \hline & & RegistrationDate : 2002-3-14 \\
& $:$ & Received \\
ArticleHistory & & Accepted 2002-3-14 \\
& $:$ 2002-3-18 \\
\hline \hline ArticleCopyright & $:$ & Biomed Central Ltd2002 \\
\hline \hline ArticleGrants & $:$ & \\
\hline \hline
\end{tabular}




\begin{tabular}{|l|l|l|l|}
\hline ArticleContext & $:$ & 1305844 \\
\hline
\end{tabular}

Julia MW Gee, ${ }^{\text {Aff1 }}$

Aff1 Tenovus Centre for Cancer Research, Welsh School of Pharmacy, Cardiff University, Wales, UK

\section{Keywords}

AKT, breast cancer, endocrine resistance, phosphorylation, survival

\section{Context}

Acquisition of endocrine resistance is a persistent problem in oestrogen receptor (ER) positive breast cancer. This phenomenon is likely to be underpinned by signalling mechanisms that enhance cell survival and proliferation. PI3 kinase/AKT signalling, which lies downstream of tyrosine kinase receptors including c-erbB2, can phosphorylate ER in a hormone independent manner and protect breast cancer cells from tamoxifen-induced apoptosis in vitro (see Additional information [1]). However, the contribution of this pathway to endocrine resistance in vivo is currently unknown. This immunocytochemical study begins to address the impact of AKT protein and its phosphorylation (pAKT) in 93 breast cancer patients treated with endocrine therapy, monitoring these parameters versus tumour clinicopathology and disease-free survival.

\section{Significant findings}

In total, $54 \%$ of tumours proved pAKT positive. pAKT was an independent predictor of distant recurrence, with a fivefold increased risk for $\mathrm{pAKT}$ positive patients. There was no parallel prognostic value for the AKT protein. pAKT was not associated with ER, PgR, bcl-2, c-erbB2, nodal status or tumour size. However, pAKT directly correlated with stromal heregulin ?1 content, perhaps confirming paracrine influences driving AKT signalling. An inverse association was noted with S-phase fraction (SPF). Further analysis revealed that a low SPF was prognostically favourable only when tumours were pAKT negative, the authors suggested that pAKT may promote distant relapse by a cell survival (rather than proliferative) mechanism. The authors conclude that AKT activation may have prognostic relevance in breast cancer. 


\section{Comments}

This article demonstrates an association between AKT phosphorylation and relapse with distant metastasis during endocrine therapy, implicating AKT signalling in the failure of endocrine therapy. Additional supportive data for AKT activation in adverse clinical breast cancer phenotypes have also recently been obtained by (see Additional information [2]). Since some expected associations were absent in the present study (e.g. correlation with c-erbB2 overexpression \{see Additional information [3]\}), it is essential that larger patient numbers are examined in order to fully validate this hypothesis. Moreover, it remains to be answered whether AKT signalling initiates endocrine resistance in vivo via an ER activation mechanism. Such studies in clinical material should now be feasible using phosphorylation state-specific antibodies available for key sites within the ER protein.

\section{Methods}

Clinical samples, flow cytometry, immunohistochemistry, phospho-specific antibody

\section{Additional information}

1. Campbell RA, Bhat-Nakshatri P, Patel NM, Constantinidou D, Ali S, Nakshatri H:

Phosphatidylinositol 3-kinase/AKT-mediated activation of estrogen receptor alpha: a new model for anti-oestrogen resistance. $J$ Biol Chem 2001, 276: 9817-9824.

2. Sun M, Wang G, Paciga JE, Feldman RI, Yuan ZQ, Ma XL, Shelley SA, Jove R, Tsichlis PN, Nicosia SV, Cheng JQ: AKT1/PKBa kinase is frequently elevated in human cancers and its constitutive activation is required for oncogenic transformation in NIH3T3 cells. Am J Pathol 2001, 159:431-437.

3. Zhou BP, Hu MC, Miller SA, Yu Z, Xia W, Lin SY, Hung MC: HER-2/neu blocks tumor necrosis factor-induced apoptosis via the Akt/NF-?B pathway. J Biol Chem 2000, 275:8027-8031. 


\section{References}

1. Perez-Tenorio G, Stal O and members of the Southeast Sweden Breast Cancer Group. : Activation of $\mathrm{AKT} / \mathrm{PKB}$ in breast cancer predicts a worse outcome among endocrine treated patients. Br J Cancer. 2002, 86: 540-545.

This PDF file was created after publication. 